\title{
Investigation of the $\mathrm{K}_{4}\left[\mathrm{Fe}(\mathrm{CN})_{6}\right]$ mediated mono- and bis- palladium-catalyzed cyanation of the benzothioxanthene core
}

\author{
Pablo Simón Marqués, ${ }^{\mathrm{a}}$ José María Andrés Castán, ${ }^{\mathrm{a}}$ Laura Abad Galan, ${ }^{\mathrm{b}}$ Magali Allain, ${ }^{\mathrm{a}}$ Olivier Maury, ${ }^{\mathrm{b}}$ \\ Tangui Le Bahers, ${ }^{\mathrm{b}}$ Philippe Blanchard, ${ }^{\mathrm{a}}$ and Clément Cabanetos ${ }^{\mathrm{a}^{*}}$ \\ ${ }^{a}$ Univ Angers, CNRS UMR 6200, MOLTECH-ANJOU, F-49000 Angers, France \\ ${ }^{\mathrm{b}}$ Univ Lyon, ENS de Lyon, CNRS UMR 5182, Université Claude Bernard Lyon 1, F-69342 Lyon, France
}

Supporting Information Placeholder

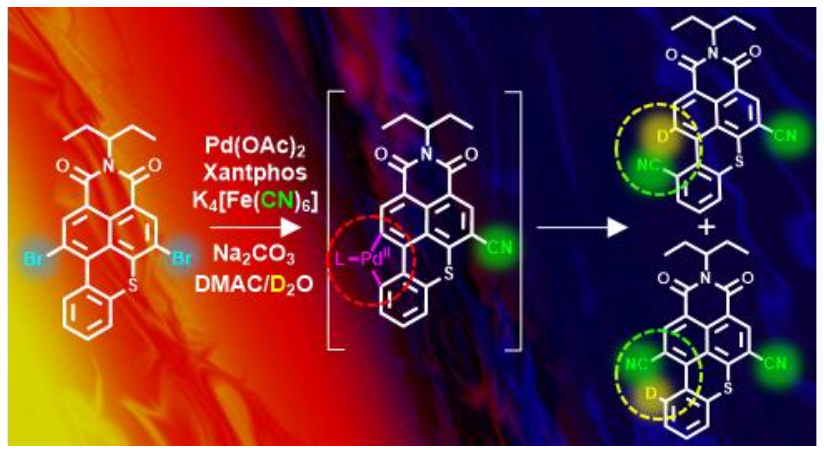

\begin{abstract}
The pallado-catalyzed cyanation of benzothioxanthene imide (BTXI) derivatives is explored herein. Once optimized on the monobromo BTXI, mild reaction conditions were successfully applied to the dibromo derivative affording two regioisomers that have been isolated and structurally solved. Additional hydrogen-deuterium exchange experiments were carried out to support a proposed mechanism involving the formation of a five-membered palladacycle intermediate in the bay area. In addition to impact the structural, photo physical and electrochemical properties of the BTXI core, nitrile moieties were successfully used as orthogonal protecting groups thus opening doors to new design
\end{abstract}

\section{- Introduction}

Over the decades, naphthalene and perylene imide derivatives have attracted considerable research attention and have emerged as iconic representatives of the rylene family. ${ }^{1-5}$ Conversely, and despite promising optical properties, the $\mathrm{N}$ (alkyl)benzothioxanthene-3,4-dicarboximide (BTXI) remained almost unnoticed, ${ }^{6}$ in particular by the organic electronic community. Moreover, their exclusive functionalization on the N-position (imide) restricted their use in bio-related ${ }^{7-8}$ and sensing applications. ${ }^{9-10}$ Recently, our group undertook an exploratory work aiming at demonstrating the efficient functionalization of this sulphur containing rylene by nitro groups $^{11}$ and halogen atoms ${ }^{12}$ to i) prepare original functional $\pi$-conjugated structures and ii) evaluate their potential in (opto)electronic devices (Figure 1). ${ }^{13-16}$

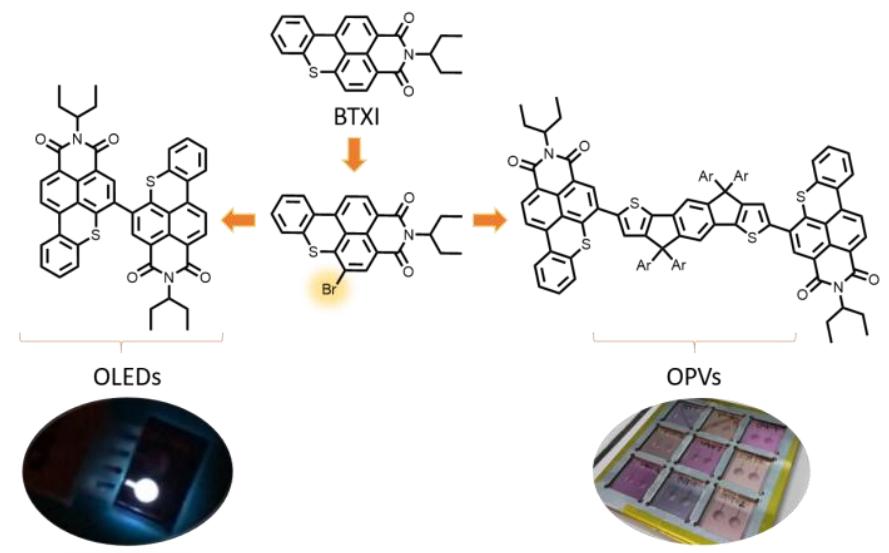

Figure 1. Chemical structure of BTXI and related examples of extended $\pi$-conjugated structures used in OLED and OPV devices.
As a further step toward the rationalization of the structureproperty relationships, we report herein the selective cyanation of this promising building block and the investigation of the impact of the nitrile groups on the electrochemical and photophysical properties. ${ }^{17-19}$

\section{- Results and discussion}

As a starting point, the conventional Rosenmund-von Braun method was firstly considered. ${ }^{20-21}$ Despite the use of a large excess of copper(I) cyanide, polar solvents and high temperatures, no conversion of the starting material was observed. ${ }^{19}$ Consequently, and considering the good reactivity of BTXI-Br in pallado catalyzed reactions, conditions reported by Beller were subsequently evaluated (Table 1 , entry 1$)^{22}$

Table1. Optimization of the cyanation conditions

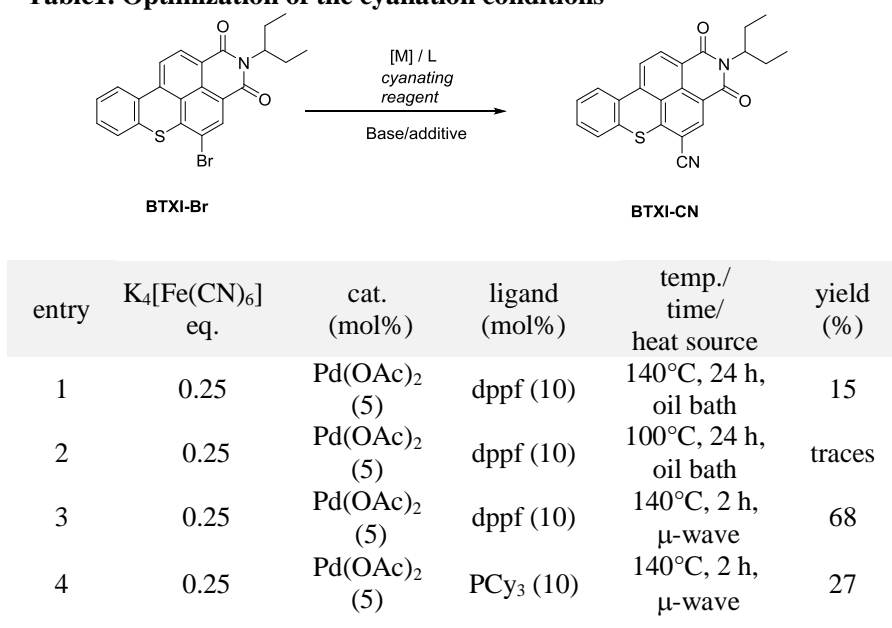




\begin{tabular}{|c|c|c|c|c|}
\hline & 0.25 & $\begin{array}{c}\mathrm{Pd}(\mathrm{OAc})_{2} \\
\quad(5)\end{array}$ & $\begin{array}{l}\text { SPhos } \\
\text { (10) }\end{array}$ & $\begin{array}{c}140^{\circ} \mathrm{C}, 2 \mathrm{~h}, \\
\mu \text {-wave }\end{array}$ \\
\hline & 0.25 & $\begin{array}{c}\mathrm{Pd}(\mathrm{OAc})_{2} \\
\quad(5)\end{array}$ & $\begin{array}{c}\text { Xantphos } \\
\text { (10) }\end{array}$ & $\begin{array}{c}140^{\circ} \mathrm{C}, 2 \mathrm{~h}, \\
\mu \text {-wave }\end{array}$ \\
\hline & 1 & $\begin{array}{c}\operatorname{Pd}(\mathrm{OAc})_{2} \\
(10)\end{array}$ & $\begin{array}{c}\text { Xantphos } \\
\text { (20) }\end{array}$ & $\begin{array}{l}140^{\circ} \mathrm{C}, 0.5 \\
\text { h, } \mu \text {-wave }\end{array}$ \\
\hline
\end{tabular}

Beyond the introduction of a catalytic system, namely the palladium(II) acetate/bis(diphenylphosphino)ferrocene ( $\left.\mathrm{Pd}(\mathrm{OAc})_{2} / \mathrm{dppf}\right)$, the toxic $\mathrm{CuCN}$ was replaced by the potassium hexacyanoferrate(II) $\left(\mathrm{K}_{4}\left[\mathrm{Fe}(\mathrm{CN})_{6}\right]\right)$ used in food industry as additive (E536). ${ }^{23-25}$ Nonetheless, while a total conversion was indeed monitored by thin layer chromatography, only a minor amount of target compound was recovered after purification. To avoid the degradation of the latter, temperature was first reduced but at the detriment of the conversion since only traces of BTXICN were isolated after $24 \mathrm{~h}$ (Table 1, entry 2). On the other hand, limiting the reaction time through the use of microwave irradiations was found to be an efficient and powerful tool to reach decent yields (Table 1, entry 3 ). In parallel, while replacing the dppf ligand by another chelating phosphine, such as the Xantphos (Table 1, entry 6), led to similar synthetic yields, the use of monodentate phosphine ligands turned out to be pernicious since they favor dehalogenation side-reactions (Table 1, Entries 4 and 5). Finally, to reduce the reaction time, the molar equivalents of both the nitrile source and the catalytic system were increased, resulting in excellent yield after only 30 minutes of $\mu \mathrm{W}$ irradiation (entry 7). It is important to note that these optimized conditions can be successfully transposed to gram scale synthesis and the purification procedure simplified by replacing the solvent consuming silica-gel chromatography by a simple filtration/precipitation of the crude (see experimental section).

Once the monocyanation of the BTXI in hands, attempts of difunctionalization were subsequently considered. To that end, the above-mentioned optimized conditions were applied to Br-BTXI$\mathbf{B r}$, ie, a dibrominated benzothioxanthene derivative (Scheme 1).

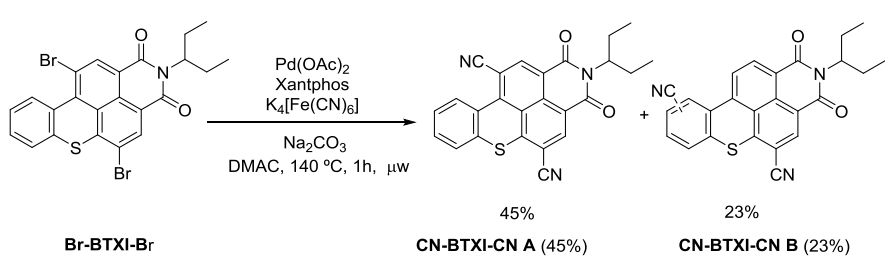

Scheme 1. Synthetic route to CN-BTXI-CN.

In addition to requiring extra 30 minutes to reach the full consumption of the starting material, the latter was systematically converted into two new products that turned out to be dicyanated regioisomers according to high resolution mass spectrometry. NMR experiments first confirmed that the major compound can be assigned to the expected CN-BTXI-CN A (Scheme 1), ie, corresponding to the substitution of the two bromine atoms by nitrile groups (Figure 2). However, while the ${ }^{1} \mathrm{H}$ NMR spectra of both Br-BTXI-Br and CN-BTXI-CN A indeed show two singlets between $9.0 \mathrm{ppm}$ and $8.5 \mathrm{ppm}$, resulting from the difunctionalization of the naphthyl block, the singlet at $8.9 \mathrm{ppm}$ splits in two doublets for the minor compound (CN-BTXI-CN B), suggesting that one of the cyano group is localized on the lower phenyl ring.

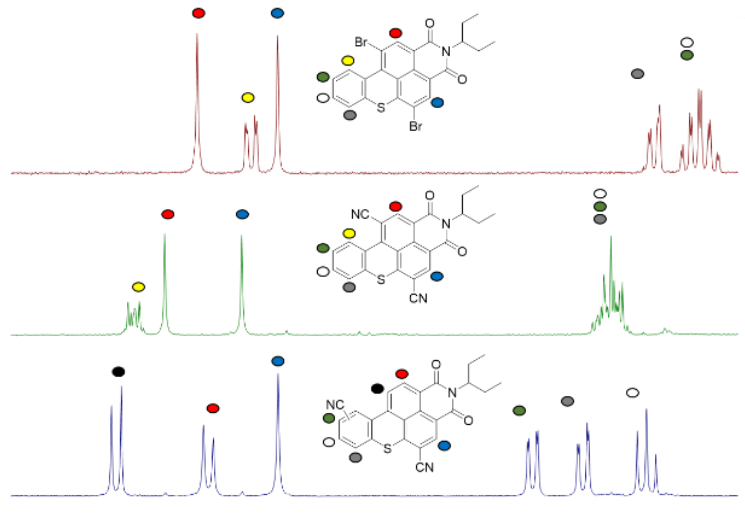

$9.39 .18 .98 .78 .5 \quad 8.38 .17 .97 .77 .57 .3$ (ppm)

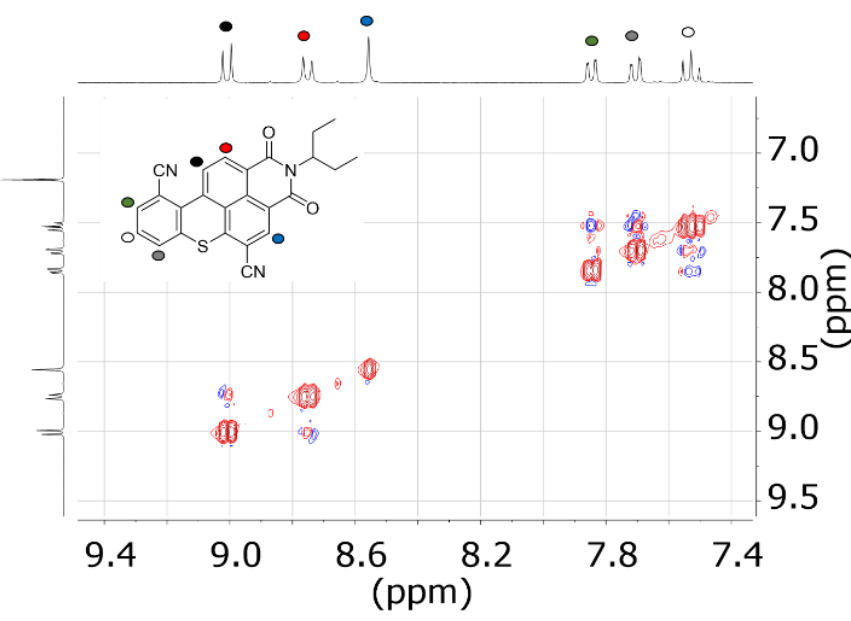

Figure 2. Comparative ${ }^{1} \mathrm{H}$ NMR spectra of Br-BTXI-Br and the two isolated bis cyanated regio isomers (top) and NOESY NMR spectra of CN-BTXI-CN B (bottom).

Carried out in parallel, NOESY NMR experiments highlighted the absence of cross relaxation between nearby bay protons that was eventually confirmed by X-ray diffraction on single crystals (Figure 2 and see SI).To rationalize this regio-isomerization, the cyanation reaction of Br-BTXI-Br was reperformed but in presence of deuterated water (Figure 3 and see SI). Integration of the corresponding ${ }^{1} \mathrm{H}$ NMR signals confirmed a deuterium-proton exchange estimated around $73 \%$ and $90 \%$ for CN-BTXI-CN A and $\mathbf{B}$ respectively. This simple but effective experiment suggests the formation of a five-membered palladacycle in the bay position generated after the oxidative addition step and subsequent elimination of $\mathrm{HBr}$ as reported on bi-aryl derivatives. ${ }^{26}$ Furthermore, the presence of deuterated CN-BTXI-CN A also highlights the reversibility of the isomerization and that most of the catalytic turnovers pass through this palladacycle complex. Consequently, two possible catalytic pathways can be considered as depicted in Scheme 2. 


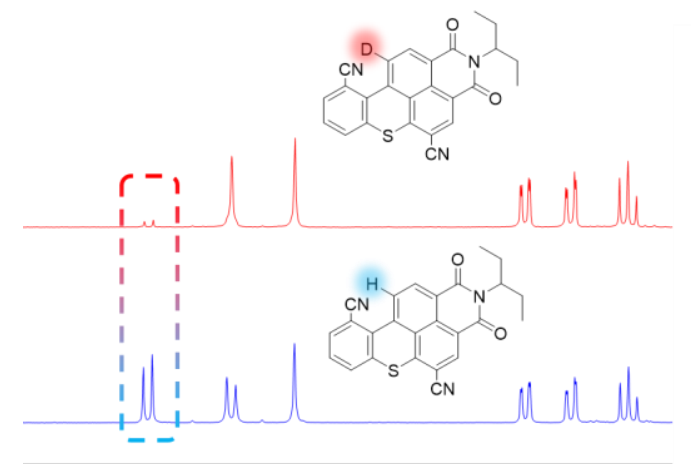

$9.49 .29 .08 .8 \quad 8.6 \quad 8.48 .28 .07 .87 .6$ $(\mathrm{ppm})$

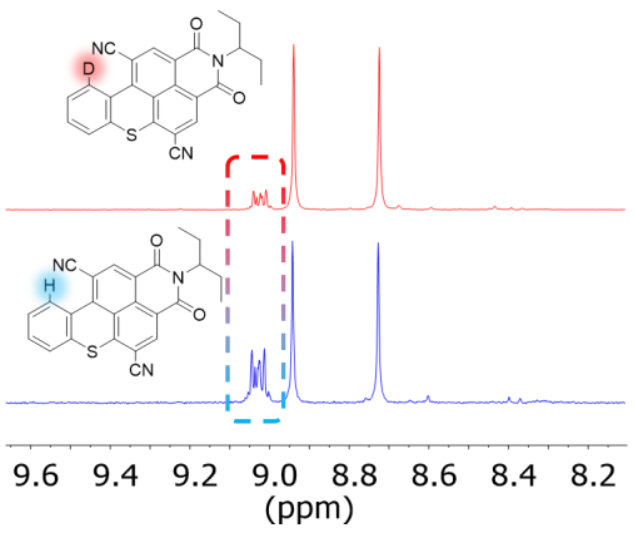

Figure 3. Comparison of ${ }^{1} \mathrm{H}$ NMR spectra of CN-BTXI-CN B (left) and CN-BTXI-CN A (right) prepared in presence (red) or absence (blue) of deuterated

Hence, following the oxidative addition of Br-BTXI-CN to $\mathrm{LnPd}^{0}$, the resulting $\mathbf{F}_{\mathbf{O A}}$ intermediate can undergo a transmetalation reaction with the nitrile source to afford $\mathbf{F}_{\mathbf{T R}} \mathbf{1}$ and therefore the "expected" CN-BTXI-CN A regioisomer through a final reductive elimination step (cycle A). In parallel, $\mathbf{F}_{\mathbf{O A}}$ can also be engaged in a remote $\mathrm{C}-\mathrm{H}$ activation process leading to the formation of the five-member palladacycle RI (cycle B). With a reversibility demonstrated by the deuterium exchange experiments, the latter can go back to $\mathbf{F}_{\mathbf{O A}}$ or move towards $\mathbf{F}_{\mathbf{E X}}$ to achieve the observed isomerization in the bay area that will further generate $\mathbf{F}_{\mathbf{T R}} \mathbf{2}$ and finally $\mathbf{C N}-\mathbf{B T X I - C N} \mathbf{B}$ via a transmetalation and subsequent a reductive elimination step. To support this proposed catalytic path, Density Functional Theory (DFT) calculation were performed in parallel (see SI). Consider- ing that i) $\mathbf{F}_{\mathbf{E X}}$ and $\mathbf{F}_{\mathbf{O A}}$ exhibit similar free energies and ii) the turnovers of the catalytic system produce deuterated species, RI appears to be a non-rate-determining reaction intermediate with an energy slightly larger than $\mathbf{F}_{\mathbf{O A}}$ ( $\left.\mathrm{ca} 13 \mathrm{kcal} / \mathrm{mol}\right)$. Consequently, with negligible difference of free energy computed between the final products, namely CN-BTXI-CN $\mathbf{A}$ and $\mathbf{B}$, the unbalanced experimental ratio might be dictated by the energy demanding reductive eliminations transition states. Once the formation of the regioisomers rationalized, the impact of the cyano group(s) on the electrochemical and optical properties of the BTXI core was subsequently investigated. Cyclic voltammetry experiments first revealed that introducing nitrile groups on the $\pi$-conjugated backbone induces a positive shift of both redox patterns and the loss of the reversibility of the oxidation peak (see SI).

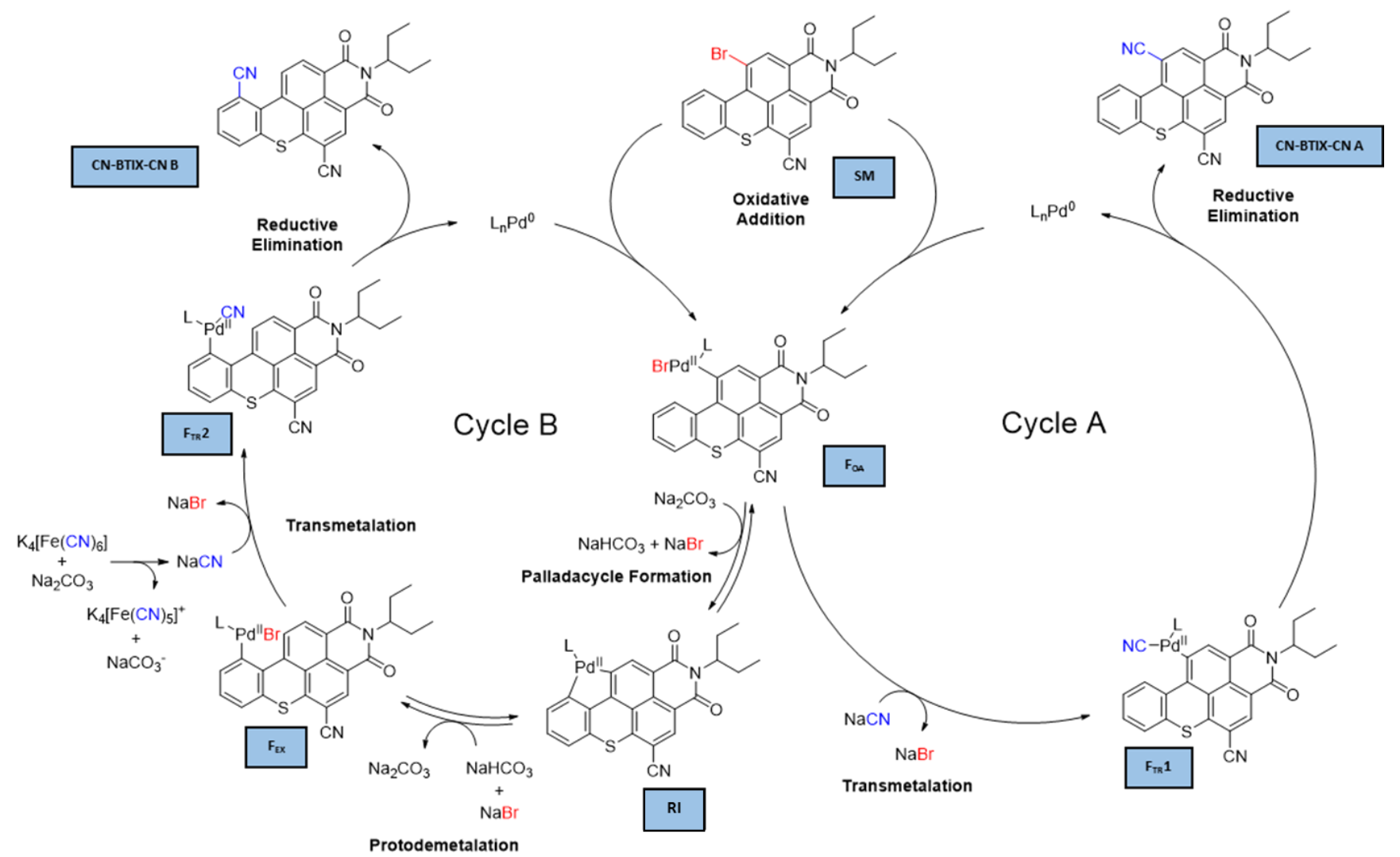

Scheme 2. Proposed mechanisms of the pallado-catalyzed cyanation of Br-BTXI-CN. 
Table 2. Electrochemical and optical data. a EHOMO $=-($ Eox $($ onset $)+4.80)(e V)$; ELUMO $=-($ Ered $($ onset $)+4.80)(e V) . b$ Measured using Coumarin-153 as reference $(\Phi f=0.45$ in methanol).c Measured using Phenalenone as reference $(\Phi \square=0.95$ in dichloromethane).

\begin{tabular}{|c|c|c|c|c|c|c|c|c|c|c|c|}
\hline $\begin{array}{l}\text { The- } \\
\text { se }\end{array}$ & Compound & $\begin{array}{l}\mathbf{E}_{\mathrm{pa}} \\
(\mathrm{V} / \mathrm{F} \\
\mathrm{c} / \mathrm{Fc}+) \\
\end{array}$ & $\begin{array}{c}\mathbf{E}_{\mathbf{p c}} \\
(\mathrm{V} / \mathrm{Fc} / \mathrm{Fc}+\end{array}$ & $\begin{array}{c}\mathbf{E}_{\text {номо }} \\
{[\mathrm{eV}]^{\mathrm{a}}}\end{array}$ & $\begin{array}{c}\mathbf{E}_{\text {LUMO }} \\
{[\mathrm{eV}]^{\mathrm{a}}}\end{array}$ & $\begin{array}{c}\lambda_{\max }{ }^{A B S} \\
(\mathbf{n m})\end{array}$ & $\begin{array}{c}\varepsilon \\
\left(\mathbf{M}^{-1} \mathrm{~cm}^{-1}\right)\end{array}$ & $\begin{array}{c}\lambda_{\max }{ }^{E M} \\
(\mathbf{n m})\end{array}$ & $\Phi_{\mathrm{f}}^{\mathbf{b}}$ & $\begin{array}{c}\tau_{\text {ob }} \\
\text { s } \\
(\mathbf{n s})\end{array}$ & $\Phi_{\Delta}^{c}$ \\
\hline $\begin{array}{l}\text { fea- } \\
\text { tures }\end{array}$ & BTXI & 0.94 & -1.81 & -5.70 & -3.03 & $\begin{array}{l}458 \\
475\end{array}$ & $\begin{array}{l}25000 \\
23500\end{array}$ & 510 & 0.99 & 7.48 & 0.00 \\
\hline $\begin{array}{l}\text { can } \\
\text { be }\end{array}$ & BTXI-CN & 1.40 & -1.46 & -6.05 & -3.38 & $\begin{array}{l}450 \\
472\end{array}$ & $\begin{array}{l}24000 \\
24000\end{array}$ & 496 & 0.87 & 6.83 & 0.07 \\
\hline $\begin{array}{l}\text { corre } \\
\text { re- } \\
\text { lated }\end{array}$ & CN-BTXI-CN A & 1.20 & -1.59 & -5.87 & -3.25 & $\begin{array}{l}463 \\
481\end{array}$ & $\begin{array}{l}13000 \\
13000\end{array}$ & 516 & 0.88 & 9.05 & 0.08 \\
\hline $\begin{array}{l}\text { to } \\
\text { the } \\
\text { elec- } \\
\text { tron- }\end{array}$ & CN-BTXI-CN B & 1.41 & -1.34 & -6.03 & -3.42 & $\begin{array}{l}448 \\
467\end{array}$ & $\begin{array}{l}23000 \\
20500\end{array}$ & 500 & 0.71 & 7.59 & 0.14 \\
\hline
\end{tabular}

withdrawing nature of the cyano moieties resulting in the stabilization the radical anion and, a contrario, destabilization of the radical cation. ${ }^{3-4,} 19$ Interestingly, while similar frontier energy levels were estimated for both BTXI-CN and CN-BTXI-CN B, the regio isomer $\mathbf{C N}-\mathbf{B T X I - C N} \mathbf{A}$ exhibits shallower HOMO and LUMO levels. This difference was also highlighted by UVVisible spectroscopy. While a minor hypsochromic shift of the 400-500 nm centered absorption band was recorded for $\mathbf{C N}$ BTXI-CN B, an appreciable bathochromic shift coupled to a significant hypochromic shift of the latter band was indeed monitored for the second regioisomer, namely CN-BTXI-CN A. These features reveal that the second cyanation, occurring at the two possible positions of the bay area, has either no or a significant impact on the energetics depending on the cyanation position.

Highly fluorescent, all compounds show analogue structured emission profiles that mostly follow the absorption trend. Once again related to the number and position of the nitrile groups, fluorescence quantum yields $\left(\Phi_{\mathrm{f}}\right)$ ranging from $71 \%$ to $88 \%$ were measured for the series ( $v s 100 \%$ for the bare BTXI). Interestingly, these results were cross-tabulated singlet-oxygen generation efficiencies $\left(\Phi_{\Delta}\right)$ revealing that the decrease of $\Phi_{\mathrm{f}}$ was counterbalanced by an increase of $\Phi_{\Delta}$. The origin of this gradient singlet-totriplet Inter-System Crossing (ISC) might be correlated to a deformation of the $\pi$-system. ${ }^{27}$ Corroborated by X-ray diffraction, the cyanation of the BTXI turns out to be an efficient strategy to break the planarity of the core since torsion angles associated with the bay area carbon atoms of $1^{\circ}, 12^{\circ}$ and $22^{\circ}$ were measured for BTXI-CN, CN-BTXI-CN A and CN-BTXI-CN B respectively (see SI). These results were further confirmed by TD-DFT calculation (see SI), highlighting the notably large spin-orbit coupling computed for the dicyano compounds, in agreement with the deformation of their $\pi$-system.

In parallel, nitrile moieties were also demonstrated as original and orthogonal protecting groups. As depicted in Scheme 3, the successive cyanation and nickel-catalyzed hydrogenolysis ${ }^{28}$ of the highly reactive position in alpha of the sulfur atom, led to the successful synthesis of Th-BTXI, corresponding to the first example of a mono functionalized BTXI derivative in the bay position.

\section{- Conclusion}

In summary, we have explored herein the pallado-catalyzed cyanation of the benzothioxanthene imide rylene. Optimized on a mono-halogenated derivative using nontoxic nitrile sources, reac- omo BTXI derivative resulting in the formation of two regio isomers.

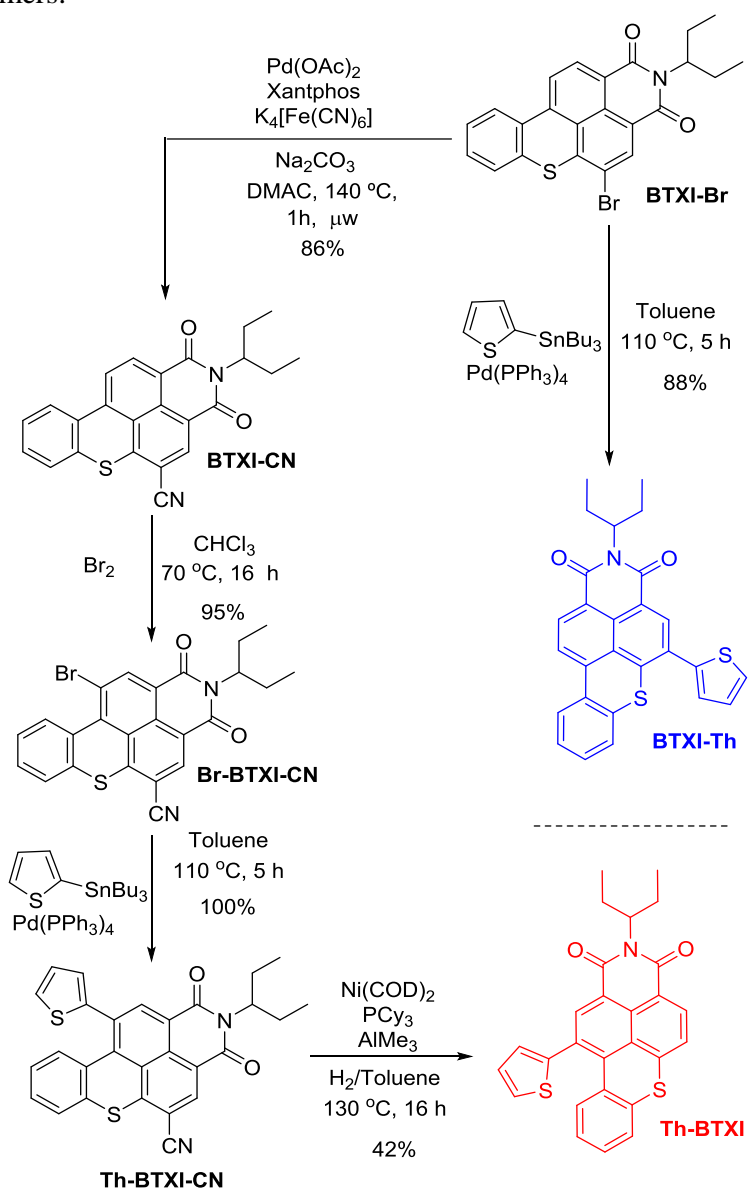

Scheme 3. Illustration of the use of a cyano moiety as protecting group for the preparation of Th-BTXI

Once structurally solved, complementary hydrogen-deuterium exchange experiments were carried out to propose a credible reaction mechanism involving a five-membered palladacycle in the bay area. Characterization of this new series of BTXI revealed that the position of the cyano groups has a significant impact on the structural, electrochemical and photophysical properties. Moreover, the latter were also demonstrated as original orthogo- 
nal protecting groups. While the transposition of the reported conditions to other rylenes is currently under study, results gathered herein clearly open doors to new design principles and broaden the range of potential applications for this highly promising dye.

\section{- Experimental section}

\section{General Experimental Details:}

$\mathrm{K}_{4}\left[\mathrm{Fe}(\mathrm{CN})_{6}\right]$ was grounded and dried at $60^{\circ} \mathrm{C}$ in vacuum prior to be used. $\mathrm{Pd}_{2}(\mathrm{dba})_{3}$ was repurified to remove $\mathrm{Pd}$ nanoparticles and dba ligand. Others purchased reagents and chemicals were used without further purification. Solvents were dried and purified using standard techniques. Microwave assisted reactions were performed in the cavity of a Biotage Initiator+ system in sealed reactors. Flash chromatography was performed with analyticalgrade solvents using Aldrich silica gel (technical grade, pore size $60 \AA$, 230-400 mesh particle size). Flexible plates ALUGRAM ${ }^{\circ}$ Xtra SIL G UV254 from MACHEREY-NAGEL were used for TLCs. Compounds were detected by UV irradiation (Bioblock Scientific). NMR spectra were recorded with a Bruker AVANCE III $300\left({ }^{1} \mathrm{H}, 300 \mathrm{MHz}\right.$ and $\left.{ }^{13} \mathrm{C}, 75 \mathrm{MHz}\right)$ or a Bruker AVANCE DRX500 $\left({ }^{1} \mathrm{H}, 500 \mathrm{MHz} ;{ }^{13} \mathrm{C}, 125 \mathrm{MHz}\right)$. Chemical shifts are given in ppm relative to TMS and coupling constants $\mathrm{J}$ in Hz. UVvis spectra were recorded with a Perkin Elmer 950 spectrometer. Matrix Assisted Laser Desorption/Ionization was performed on MALDI-TOF MS BIFLEX III Bruker Daltonics spectrometer. High-resolution mass spectrometry (HRMS) was performed with a JEOL JMS-700 B/E or a JEOL Spiral-TOF JMS3000. Cyclic voltammetry was performed using a BIOLOGIC SP-150 potentiostat with positive feedback compensation in $0.10 \mathrm{M}$ $\mathrm{Bu}_{4} \mathrm{NPF}_{6} / \mathrm{CH}_{2} \mathrm{Cl}_{2}$ (HPLC grade). Experiments were carried out in a one-compartment cell equipped with a platinum working electrode (2 $\mathrm{mm}$ of diameter) and a platinum wire counter electrode. A silver wire immersed in a $0.01 \mathrm{M}$ solution of $\mathrm{AgNO}_{3}$ in $\mathrm{CH}_{3} \mathrm{CN}$ was used as pseudo-reference electrode and checked against the ferrocene/ferrocenium couple $(\mathrm{Fc} / \mathrm{Fc}+)$ before and after each experiment. The potentials were then expressed vs $\mathrm{Fc} / \mathrm{Fc}+$. UV-vs spectra were recorded on a PERKIN ELMER 950 spectrometer.

$\mathrm{X}$-ray single-crystal diffraction data were collected on a Rigaku Oxford Diffraction SuperNova diffractometer equipped with Atlas $\mathrm{CCD}$ detector and micro-focus $\mathrm{Cu}-\mathrm{K} \alpha$ radiation. The structures were solved by dual-space algorithm and refined on F2 by full matrix least-squares techniques using SHELX programs (G. M. Sheldrick 2018 for SHELXT and SHELXL). All non-H atoms were refined anisotropically and multiscan empirical absorption was corrected using CrysAlisPro program (CrysAlisPro V 1.171.40.45a, Rigaku OD, 2019). The $\mathrm{H}$ atoms were placed at calculated positions and refined using a riding model.

\section{Synthesis}

General procedure for $\mathrm{K}_{4}\left[\mathrm{Fe}(\mathrm{CN})_{6}\right]$ mediated cyanation: 5bromo-2-(pentan-3- yl)-1H-thioxantheno[2,1,9-def]isoquinoline1,3(2H)-dione (BTXI-Br) (50 mg, $110.54 \mu \mathrm{mol}), \mathrm{K}_{4}\left[\mathrm{Fe}(\mathrm{CN})_{6}\right]$ (10 mg, $27.63 \mu \mathrm{mol})$, sodium carbonate $(12 \mathrm{mg}, 110.53 \mu \mathrm{mol})$, palladium source $(5.53 \mu \mathrm{mol})$ and the phosphine ligand $(11.05$ $\mu \mathrm{mol})$ were added into a microwave reactor. Once sealed and purged under argon atmosphere, $3 \mathrm{~mL}$ of N,N-dimethylacetamide were added. The mixture was then irradiated in the microwave cavity with a pre-selected temperature from $100{ }^{\circ} \mathrm{C}$ to $140{ }^{\circ} \mathrm{C}$. The reaction mixture was then cooled to room temperature and the solvent removed under vacuum. The crude was purified by column chromatography on silica gel using dichloromethane as the eluent to obtain a yellow solid $(95 \%)$. Purification protocol B:
The crude was solubilized in dichloromethane and passed through a silica plug. The filtered solution was then concentrated under reduced pressure. The resulting solid was triturated in a methanol/dichloromethane mixture (4:1), filtrated and successively washed with hot methanol and distilled pentane to afford a yellow solid $(86 \%)$.

BTXI-CN: ${ }^{1} \mathrm{H}-\mathrm{NMR}(300 \mathrm{MHz}, \mathrm{CDCl} 3): \delta 8.75(\mathrm{~d}, \mathrm{~J}=8.2 \mathrm{~Hz}$, $1 \mathrm{H}), 8.60(\mathrm{~s}, 1 \mathrm{H}), 8.39(\mathrm{~d}, \mathrm{~J}=8.4 \mathrm{~Hz}, 1 \mathrm{H}), 8.34-8.28(\mathrm{~m}, 1 \mathrm{H})$, $7.60-7.50(\mathrm{~m}, 3 \mathrm{H}), 5.03(\mathrm{tt}, \mathrm{J}=9.4,5.7 \mathrm{~Hz}, 1 \mathrm{H}), 2.31-2.12(\mathrm{~m}$, $2 \mathrm{H}), 1.98-1.84(\mathrm{~m}, 2 \mathrm{H}), 0.89(\mathrm{t}, \mathrm{J}=7.5 \mathrm{~Hz}, 8 \mathrm{H}) .{ }^{13} \mathrm{C} \mathrm{NMR}(125$ $\left.\mathrm{MHz}, \mathrm{CDCl}_{3}\right): \delta 146.5,136.9,134.5,133.5,133.5,131.3,130.8$, $130.2,128.9,127.6,127.2,126.5,125.5,120.9,115.9,103.6$, 58.1, 25.1, 11.4. HRMS (EI+): calculated for $\mathrm{C}_{24} \mathrm{H}_{18} \mathrm{~N}_{2} \mathrm{O}_{2} \mathrm{~S}$ 398.1083, found 398.1088.

Scaled up synthesis of BTXI-CN: Two $20 \mathrm{~mL}$ microwave reactors were charged with 5-bromo-2-(pentan-3- yl)-1Hthioxantheno[2,1,9-def]isoquinoline-1,3(2H)-dione (BTXI-Br) (500 mg, $1.11 \mathrm{mmol}), \mathrm{K}_{4}\left[\mathrm{Fe}(\mathrm{CN})_{6}\right](407 \mathrm{mg}, 1.11 \mathrm{mmol})$, sodium carbonate $(175 \mathrm{mg}, 1.11 \mu \mathrm{mol})$, palladium(II) acetate $(50 \mathrm{mg}, 0.22$ $\mathrm{mmol}$ ) and Xantphos (255 mg, $0.44 \mathrm{mmol})$. Once under inert atmosphere, $20 \mathrm{~mL}$ of $\mathrm{N}, \mathrm{N}$-dimethylacetamide were added and the reaction mixture were subsequently irradiated in the microwave cavity at $140{ }^{\circ} \mathrm{C}$. After $1 \mathrm{~h}$ of reaction and cooled to room temperature, the two reaction mixture were mixed together. The solvent was then removed under vacuum and the product purified following either the purification protocol A (79\% yield) or B ( $70 \%$ yield).

Synthesis of $\boldsymbol{C N}$-BTXI-CN: Anhydrous N,N-dimethylacetamide (3 mL) was added to a mixture of 5,11-dibromo-2-(pentan-3-yl)1H-thioxantheno[2,1,9-def]isoquinoline-1,3(2H)-dione $\quad(\mathbf{B r}-$ BTXI-Br) $(50 \mathrm{mg}, 94.12 \mu \mathrm{mol}), \mathrm{K}_{4}\left[\mathrm{Fe}(\mathrm{CN})_{6}\right](69 \mathrm{mg}, 180.23$ $\mu \mathrm{mol})$, sodium carbonate $(15 \mathrm{mg}, 141.17 \mu \mathrm{mol})$, palladium(II) acetate $(50 \mathrm{mg}, 18.82 \mu \mathrm{mol})$ and Xantphos $(22 \mathrm{mg}, 37.65 \mu \mathrm{mol})$. The reaction mixture was then stirred for $1 \mathrm{~h}$ in the microwave cavity at $140{ }^{\circ} \mathrm{C}$. The reaction mixture was cooled to room temperature and the solvent removed under vacuum. The crude was purified by silica gel column chromatography using dichloromethane as eluent to obtain $18 \mathrm{mg}$ of CN-BTXI-CN A $(45 \%$ yield) in the first fraction and $9 \mathrm{mg}$ of CN-BTXI-CN B $(23 \%$ yield) in the second fraction, both of them as a yellow solids.

CN-BTXI-CN A: ${ }^{1} \mathrm{H}-\mathrm{NMR}\left(300 \mathrm{MHz}, \mathrm{CDCl}_{3}\right): \delta 9.06-9.00(\mathrm{~m}$, $1 \mathrm{H}), 8.94(\mathrm{~s}, 1 \mathrm{H}), 8.73(\mathrm{~s}, 1 \mathrm{H}), 7.76-7.64(\mathrm{~m}, 3 \mathrm{H}), 5.06-5.00(\mathrm{~m}$, $1 \mathrm{H}), 2.31-2.10(\mathrm{~m}, 2 \mathrm{H}), 2.02-1.83(\mathrm{~m}, 2 \mathrm{H}), 0.88(\mathrm{t}, \mathrm{J}=7.5 \mathrm{~Hz}$, $6 \mathrm{H}) .{ }^{13} \mathrm{C}$ NMR $\left(75 \mathrm{MHz}, \mathrm{CDCl}_{3}\right): \delta 146.1,140.7,139.0,134.9$, $132.2,131.8,131.6,129.8,129.1,127.2,126.5,125.8,122.3$, 119.1, 115.2, 106.0, 105.3, 58.3, 24.7, 11.2. HRMS (FAB-): calculated for $\mathrm{C}_{25} \mathrm{H}_{17} \mathrm{~N}_{3} \mathrm{O}_{2} \mathrm{~S} 423.1036$, found 423.1041 .

CN-BTXI-CN B: ${ }^{1} \mathrm{H}-\mathrm{NMR}\left(300 \mathrm{MHz}, \mathrm{CDCl}_{3}\right): \delta 9.07-9.00(\mathrm{~m}$, $1 \mathrm{H}), 8.94(\mathrm{~s}, 1 \mathrm{H}), 8.73(\mathrm{~s}, 1 \mathrm{H}), 7.76-7.64(\mathrm{~m}, 3 \mathrm{H}), 5.06-4.94(\mathrm{~m}$, $1 \mathrm{H}), 2.29-2.11(\mathrm{~m}, 2 \mathrm{H}), 2.01-1.84(\mathrm{~m}, 2 \mathrm{H}), 0.88(\mathrm{t}, \mathrm{J}=7.5 \mathrm{~Hz}$, $6 \mathrm{H}) .{ }^{13} \mathrm{C} \mathrm{NMR}\left(75 \mathrm{MHz}, \mathrm{CDCl}_{3}\right): \delta 143.75,136.98,133.72$, $133.49,131.19,130.48,130.00,129.83,127.01,125.81,118.97$, 115.53, 111.73, 104.33, 58.22, 24.93, 11.39. HRMS (FAB-): calculated for $\mathrm{C}_{25} \mathrm{H}_{17} \mathrm{~N}_{3} \mathrm{O}_{2} \mathrm{~S} 423.1036$, found 423.1048 .

Synthesis of Br-BTXI-CN: Bromine (129 $\mu \mathrm{L}, 401 \mathrm{mg}, 2.5 \mathrm{mmol})$ was added to a solution of BTXI-CN $(50 \mathrm{mg}, 0.13 \mathrm{mmol})$ in dichloromethane $(5 \mathrm{~mL})$. The reaction mixture was refluxed for $16 \mathrm{~h}$ before being washed with saturated $\mathrm{Na}_{2} \mathrm{~S}_{2} \mathrm{O}_{3}$, water and brine. Once dried over $\mathrm{MgSO}_{4}$, the solvent was removed by rotary evaporation and the crude was subjected to silica gel column chromatography using toluene as eluent. $57 \mathrm{mg}$ of the final product were obtained as an orange solid ( $95 \%$ yield). ${ }^{1} \mathrm{H}-\mathrm{NMR}(300$ $\left.\mathrm{MHz}, \mathrm{CDCl}_{3}\right): \delta 8.93(\mathrm{~s}, 1 \mathrm{H}), 8.76(\mathrm{dd}, \mathrm{J}=7.8,1.8 \mathrm{~Hz}, 1 \mathrm{H}), 8.57$ (s, 1H), $7.60(\mathrm{dd}, \mathrm{J}=7.6,1.8 \mathrm{~Hz}, 1 \mathrm{H}), 7.60(\mathrm{dd}, \mathrm{J}=7.6,1.8 \mathrm{~Hz}$, 
1H), $7.56-7.43(\mathrm{~m}, 2 \mathrm{H}), 5.05-4.93(\mathrm{~m}, 1 \mathrm{H}), 2.20(\mathrm{~m}, 2 \mathrm{H}), 1.97$ $-1.82(\mathrm{~m}, 2 \mathrm{H}), 0.87(\mathrm{t}, \mathrm{J}=7.4 \mathrm{~Hz}, 1 \mathrm{H}) .{ }^{13} \mathrm{C} \mathrm{NMR}(75 \mathrm{MHz}$, $\left.\mathrm{CDCl}_{3}\right): \delta 162.9,162.6,144.8,140.8,137.0,132.9,131.3,131.1$, $130.8,129.2$, 129.0, 128.0, 127.4, 127.2, 122.2, 119.2, 118.6, 115.8, 105.0, 58.2, 24.9, 11.4. HRMS (FAB-): calculated for $\mathrm{C}_{24} \mathrm{H}_{17} \mathrm{BrN}_{2} \mathrm{O}_{2} \mathrm{~S}$ 476.0189; found 476.0981.

Synthesis of Th-BTXI-CN: To a mixture of Br-BTXI-CN (50 mg, $104.74 \mu \mathrm{mol}$ ) and tributyl(thiophen-2-yl)stannane (78 mg, 209,48 $\mu \mathrm{mol})$ was added in degassed toluene $(3 \mathrm{~mL}) . \mathrm{Pd}\left(\mathrm{PPh}_{3}\right)_{4}(6 \mathrm{mg}$, $5.24 \mu \mathrm{mol})$ was then added before refluxing the mixture for $16 \mathrm{~h}$ under inert atmosphere. The reaction was cooled to room temperature and the solvent removed under vacuum. Purification of the crude was performed by column chromatography on silica gel using dichloromethane as the eluent affording $50 \mathrm{mg}$ of an orange solid $\left(100 \%\right.$ yield). ${ }^{1} \mathrm{H}-\mathrm{NMR}\left(300 \mathrm{MHz}, \mathrm{CDCl}_{3}\right): \delta 8.81(\mathrm{~s}, 1 \mathrm{H})$, $8.59(\mathrm{~s}, 1 \mathrm{H}), 7.66(\mathrm{dd}, \mathrm{J}=8.4,0.9 \mathrm{~Hz}, 1 \mathrm{H}), 7.55(\mathrm{dd}, \mathrm{J}=8.0,1.1$ $\mathrm{Hz}, 1 \mathrm{H}), 7.41(\mathrm{dd}, \mathrm{J}=5.1,1.2 \mathrm{~Hz}, 1 \mathrm{H}), 7.34(\mathrm{td}, \mathrm{J}=7.7,1.2 \mathrm{~Hz}$, $1 \mathrm{H}), 7.21(\mathrm{dd}, \mathrm{J}=3.6,1.2 \mathrm{~Hz}, 1 \mathrm{H}), 7.11-7.03(\mathrm{~m}, 2 \mathrm{H}), 5.08-$ $4.96(\mathrm{~m}, 1 \mathrm{H}), 2.33-2.12(\mathrm{~m}, 2 \mathrm{H}), 2.00-1.79(\mathrm{~m}, 2 \mathrm{H}), 0.88(\mathrm{t}, \mathrm{J}$ $=7.5 \mathrm{~Hz}, 6 \mathrm{H}) .{ }^{13} \mathrm{C} \mathrm{NMR}\left(75 \mathrm{MHz}, \mathrm{CDCl}_{3}\right): \delta 163.7,163.6,146.2$, $143.8,138.8,136.3,132.9,132.1,131.5,131.3,129.9,129.6$, $128.7,128.6,128.4,127.9,127.8,127.3,127.2,121.6,119.2$, 116.1, 104.7, 58.0, 25.0, 11.4. HRMS (MALDI+): calculated for $\mathrm{C}_{28} \mathrm{H}_{20} \mathrm{~N}_{2} \mathrm{O}_{2} \mathrm{~S}_{2}$ 480.0961; found.480.0968.

Synthesis of Th-BTXI: An oven-dried screw-cap reaction tube was charged with Th-BTXI-CN (30 mg, $62.42 \mu \mathrm{mol}), \mathrm{Ni}(\mathrm{COD})_{2}$ $(5 \mathrm{mg}, 18.73 \mu \mathrm{mol})$ and $\mathrm{PCy}_{3}(16 \mathrm{mg}, 56.18 \mu \mathrm{mol})$ inside a glovebox under inert atmosphere. The tube was sealed and taken out from the glovebox before repeating three vacuum-hydrogen cycles. Then, degassed toluene $(3 \mathrm{~mL})$ and $\mathrm{AlMe}_{3}(94 \mu \mathrm{L}, 187.27$ $\mu \mathrm{mol}, 2 \mathrm{M}$ in toulene) were added and the reaction was heated at $130{ }^{\circ} \mathrm{C}$ for $16 \mathrm{~h}$. Thereafter, the mixture was cooled to room temperature and the crude filtrated through celite using ethyl acetate as eluent. The filtrate was concentrated before being purified by column chromatography using dichloromethane as eluent. Finally, $12 \mathrm{mg}$ of the expected product were obtained as an orange solid (42\% yield) whereas $5 \mathrm{mg}$ of the starting material Th-BTXI-CN (18\% yield) were recovered. ${ }^{1} \mathrm{H}-\mathrm{NMR}\left(300 \mathrm{MHz}, \mathrm{CDCl}_{3}\right): \delta 8.63$ $(\mathrm{s}, 1 \mathrm{H}), 8.33(\mathrm{~d}, \mathrm{~J}=7.9 \mathrm{~Hz}, 1 \mathrm{H}), 7.59-7.48(\mathrm{~m}, 2 \mathrm{H}), 7.38-7.26$ $(\mathrm{m}, 2 \mathrm{H}), 7.18-7.09(\mathrm{~m}, 2 \mathrm{H}), 7.00(\mathrm{dd}, \mathrm{J}=5.1,3.5 \mathrm{~Hz}, 1 \mathrm{H}), 6.92$ $(\mathrm{ddd}, \mathrm{J}=8.5,7.2,1.5 \mathrm{~Hz}, 1 \mathrm{H}), 5.06-4.92(\mathrm{~m}, 2 \mathrm{H}), 2.28-2.11$ $(\mathrm{m}, 2 \mathrm{H}), 1.88-1.78(\mathrm{~m}, 2 \mathrm{H}), 0.82(\mathrm{t}, \mathrm{J}=7.5 \mathrm{~Hz}, 6 \mathrm{H}) .{ }^{13} \mathrm{C} \mathrm{NMR}$ $\left(75 \mathrm{MHz}, \mathrm{CDCl}_{3}\right): \delta 144.5,139.9,137.0,136.1,133.3,132.0$, $129.9,129.4,129.1,129.0,128.0,127.4,127.3,127.0,126.9$, 126.7, 126.3, 121.6, 57.5, 25.0, 11.3. HRMS (MALDI+): calculated for $\mathrm{C}_{27} \mathrm{H}_{21} \mathrm{NO}_{2} \mathrm{~S}_{2} 455.1008$; found 455.1015 .

Synthesis of BTXI-Th: 5-bromo-2-(pentan-3- $\mathrm{yl})-1 \mathrm{H}-$ thioxantheno[2,1,9-def]isoquinoline-1,3(2H)-dione (BTXI-Br) (100 mg, $0.22 \mathrm{mmol})$, tributyl(thiophen-2-yl)stannane $(140 \mu \mathrm{L}$, $165 \mathrm{mg}, 0.44 \mathrm{mmol})$ and $\mathrm{Pd}\left(\mathrm{PPh}_{3}\right)_{4}(13 \mathrm{mg}, 11.05 \mu \mathrm{mol})$ were dissolved in dry and degassed toluene $(7 \mathrm{~mL})$. The reaction mixture was then stirred and refluxed for $5 \mathrm{~h}$ under inert conditions. Once concentrated under vacuum, the crude was purified by column chromatography using dichloromethane as eluent thus affording $89 \mathrm{mg}$ of an orange powder $\left(88 \%\right.$ yield). ${ }^{1} \mathrm{H}-\mathrm{NMR}(300$ $\left.\mathrm{MHz}, \mathrm{CDCl}^{3}\right): \delta 8.61(\mathrm{~d}, \mathrm{~J}=8.2 \mathrm{~Hz}, 1 \mathrm{H}), 8.48(\mathrm{~s}, 1 \mathrm{H}), 8.24(\mathrm{~d}, \mathrm{~J}=$ $8.3 \mathrm{~Hz}, 1 \mathrm{H}), 8.22-8.17(\mathrm{~m}, 1 \mathrm{H}), 7.53(\mathrm{dd}, \mathrm{J}=5.1,1.2 \mathrm{~Hz}, 1 \mathrm{H})$, $7.43-7.30(\mathrm{~m}, 4 \mathrm{H}), 7.22(\mathrm{dd}, \mathrm{J}=5.1,3.5 \mathrm{~Hz}, 1 \mathrm{H}), 5.06(\mathrm{tt}, \mathrm{J}=$ 9.6, 5.8 Hz, 1H), $2.39-2.14(\mathrm{~m}, 2 \mathrm{H}), 2.01-1.82(\mathrm{~m}, 2 \mathrm{H}), 0.90$ $(\mathrm{t}, \mathrm{J}=7.5 \mathrm{~Hz}, 6 \mathrm{H}) .{ }^{13} \mathrm{C}$ NMR $\left(75 \mathrm{MHz}, \mathrm{CDCl}^{3}\right): \delta 164.8,140.1$, $139.0,136.8,133.6,132.4,131.8,129.9,129.8,128.2,127.7$, $127.6,127.5,127.2,126.7,126.6,126.1,125.9$, 121.6, 119.5, 117.8, 57.4, 25.0, 11.4. HRMS (MALDI+): calculated for $\mathrm{C}_{27} \mathrm{H}_{21} \mathrm{NO}_{2} \mathrm{~S}_{2}$ 455.1008; found 455.1009.
Isotopic labeling experiments: Dicyanation reaction was carried out following the same procedure described above in presence of $100 \mu \mathrm{L}$ of $\mathrm{D}_{2} \mathrm{O}$. Both regioisomers were isolated in similar yields and analysed by ${ }^{1} \mathrm{H}$ NMR (Figure S34-36) and MS spectrometry (Figure S47-48) to evaluate the presence of deuterated species.

\section{ASSOCIATED CONTENT \\ Supporting Information}

The Supporting Information is available free of charge on the ACS Publications website.

\section{AUTHOR INFORMATION \\ Corresponding Author}

*clement.cabanetos@univ-angers.fr

\section{Author Contributions}

The manuscript was written through contributions of all authors. All authors have given approval to the final version of the manuscript.

\section{ACKNOWLEDGMENT}

Authors thank the MATRIX SFR of the University of Angers. J.M.A.C. and P.S.M. thanks the European Union's Horizon 2020 research and innovation program under Marie Sklodowska Curie Grant agreement No.722651 (SEPOMO). The Région Pays de la Loire is also acknowledged for the Project "étoiles montantes" SAMOA. L.A.G. acknowledges the French Agence Nationale de la Recherche for her grant (ANR SADAM ANR-16-CE070015-02).

\section{REFERENCES}

1. Nowak-Król, A.; Würthner, F., Progress in the synthesis of perylene bisimide dyes. Organic Chemistry Frontiers 2019, 6 (8), 1272-1318.

2. Feng, J.; Jiang, W.; Wang, Z., Synthesis and Application of Rylene Imide Dyes as Organic Semiconducting Materials. Chemistry - An Asian Journal 2018, 13 (1), 20-30.

3. Chen, L.; Li, C.; Müllen, K., Beyond perylene diimides: synthesis, assembly and function of higher rylene chromophores. Journal of Materials Chemistry C 2014, 2 (11), 1938-1956.

4. Huang, C.; Barlow, S.; Marder, S. R., Perylene-3,4,9,10tetracarboxylic Acid Diimides: Synthesis, Physical Properties, and Use in Organic Electronics. The Journal of Organic Chemistry 2011, 76 (8), 23862407

5. Guo, X.; Facchetti, A.; Marks, T. J., Imide- and AmideFunctionalized Polymer Semiconductors. Chemical Reviews 2014, 114 (18), 8943-9021.

6. Grayshan, P. H.; Kadhim, A. M.; Perters, A. T., Heterocyclic derivalives of naphthalene-1,8-dicar boxylie anhydride. Part III. Benzo[k,1] thioxanthene-3,4-dicarboximides. J. Heterocycl. Chem. 1974, 11 (1), 33-38.

7. Mao, P.; Qian, X.; Zhang, H.; Yao, W., Benzothioxanthene dyes as fluorescent label for DNA hybridization: synthesis and application. Dyes Pigm. 2004, 60 (1), 9-16.

8. Qian, X.; Mao, P.; Yao, W.; Guo, X., Synthesis and properties of benzothioxanthene dicarboximide hydroperoxide: an efficient 'time-resolved' DNA photocleaver with long-wavelength. Tetrahedron Lett. 2002, 43 (16), 2995-2998.

9. Zhi-Zhang, L.; Cheng-Gang, N.; Guang-Ming, Z.; Pin-Zhu, Q., Fluorescence Sensor for Water Content in Organic Solvents Based on Covalent Immobilization of Benzothioxanthene. Chem. Lett. 2009, 38 (7), 698-699.

10. Danko, M.; Chmela, Š.; Hrdlovič, P., Synthesis, photochemical stability and photo-stabilizing efficiency of probes based on benzothioxanthene chromophore and Hindered Amine Stabilizer. Polym. Degrad. Stab. 2006, 91 (5), 1045-1051.

11. Andrés Castán, J. M.; Abad Galán, L.; Li, S.; Dalinot, C.; Simón Marqués, P.; Allain, M.; Risko, C.; Monnereau, C.; Maury, O.; Blanchard, P.; Cabanetos, C., Nitration of benzothioxanthene: towards a new class of dyes with versatile photophysical properties. New J. Chem. 2020, 44 (3), 900-905.

12. Dalinot, C.; Simón Marqués, P.; Andrés Castán, J. M.; Josse, P.; Allain, M.; Abad Galán, L.; Monnereau, C.; Maury, O.; Blanchard, P.; Cabanetos, C., Regioselective Monohalogenation and Homo/Hetero 
Dihalogenation of Benzothioxanthene Monoimide. Eur. J. Org. Chem. 2020, 2020 (14), 2140-2145.

13. Josse, P.; Li, S.; Dayneko, S.; Joly, D.; Labrunie, A.; DabosSeignon, S.; Allain, M.; Siegler, B.; Demadrille, R.; Welch, G. C.; Risko, C.; Blanchard, P.; Cabanetos, C., Bromination of the benzothioxanthene Bloc: toward new $\pi$-conjugated systems for organic electronic applications. J. Mater. Chem. C 2018, 6 (4), 761-766.

14. Andrés Castán, J. M.; Dalinot, C.; Dayneko, S.; Abad Galan, L.; Simón Marqués, P.; Alévêque, O.; Allain, M.; Maury, O.; Favereau, L. Blanchard, P.; Welch, G. C.; Cabanetos, C., Synthesis, characterization and use of benzothioxanthene imide based dimers. Chem. Commun. 2020, 56 (70), 10131-10134

15. Payne, A.-J.; Rice, N. A.; McAfee, S. M.; Li, S.; Josse, P.; Cabanetos, C.; Risko, C.; Lessard, B. H.; Welch, G. C., Donor or Acceptor? How Selection of the Rylene Imide End Cap Impacts the Polarity of $\pi$ Conjugated Molecules for Organic Electronics. ACS Appl. Energy. Mater. 2018, 1 (9), 4906-4916.

16. Dayneko, S. V.; Hendsbee, A. D.; Cann, J. R.; Cabanetos, C.; Welch, G. C., Ternary organic solar cells: using molecular donor or acceptor third components to increase open circuit voltage. New J. Chem. 2019, 43 (26), $10442-10448$

17. Delgado, M. C. R.; Kim, E.-G.; Filho, D. A. d. S.; Bredas, J.-L. Tuning the Charge-Transport Parameters of Perylene Diimide Single Crystals via End and/or Core Functionalization: A Density Functional Theory Investigation. J. Am. Chem. Soc. 2010, 132 (10), 3375-3387.

18. Gao, J.; Xiao, C.; Jiang, W.; Wang, Z., Cyano-Substituted Perylene Diimides with Linearly Correlated LUMO Levels. Org. Lett. 2014, 16 (2), 394397.

19. Ahrens, M. J.; Fuller, M. J.; Wasielewski, M. R., Cyanated Perylene-3,4-dicarboximides and Perylene-3,4:9,10-bis(dicarboximide): Facile Chromophoric Oxidants for Organic Photonics and Electronics. Chem. Mater. 2003, 15 (14), 2684-2686.

20. Koelsch, C. F.; Whitney, A. G., THE ROSENMUND-von BRAUN NITRILE SYNTHESIS1. The Journal of Organic Chemistry 1941, 06 (6), $795-$ 803 .

21. Ellis, G. P.; Romney-Alexander, T. M., Cyanation of aromatic halides. Chem. Rev. 1987, 87 (4), 779-794.

22. Schareina, T.; Zapf, A.; Beller, M., Improving palladium-catalyzed cyanation of aryl halides: development of a state-of-the-art methodology using potassium hexacyanoferrate(II) as cyanating agent. J. Organomet. Chem. 2004, 689 (24), 4576-4583.

23. Yan, G.; Kuang, C.; Zhang, Y.; Wang, J., Palladium-Catalyzed Direct Cyanation of Indoles with $\mathrm{K} 4[\mathrm{Fe}(\mathrm{CN}) 6]$. Org. Lett. 2010, 12 (5), 1052 1055.

24. Jia, X.; Yang, D.; Wang, W.; Luo, F.; Cheng, J., ChelationAssisted Palladium-Catalyzed Cascade Bromination/Cyanation Reaction of 2 Arylpyridine and 1-Arylpyrazole $\mathrm{C}-\mathrm{H}$ Bonds. The Journal of Organic Chemistry 2009, 74 (24), 9470-9474.

25. Gerber, R.; Oberholzer, M.; Frech, C. M., Cyanation of Aryl Bromides with $\mathrm{K} 4[\mathrm{Fe}(\mathrm{CN}) 6]$ Catalyzed by Dichloro[bis $\{1$ (dicyclohexylphosphanyl)piperidine \}]palladium, a Molecular Source of Nanoparticles, and the Reactions Involved in the Catalyst-Deactivation Processes. Chemistry - A European Journal 2012, 18 (10), 2978-2986.

26. Campo, M. A.; Zhang, H.; Yao, T.; Ibdah, A.; McCulla, R. D.; Huang, Q.; Zhao, J.; Jenks, W. S.; Larock, R. C., Aryl to Aryl Palladium Migration in the Heck and Suzuki Coupling of o-Halobiaryls. J. Am. Chem Soc. 2007, 129 (19), 6298-6307.

27. Galán, L. A.; Andrés Castán, J. M.; Dalinot, C.; Marqués, P. S.; Blanchard, P.; Maury, O.; Cabanetos, C.; Le Bahers, T.; Monnereau, C., Theoretical and experimental investigation on the intersystem crossing kinetics in benzothioxanthene imide luminophores, and their dependence on substituen effects. Physical Chemistry Chemical Physics 2020, 22 (22), 12373-12381.

28. Patra, T.; Agasti, S.; Modak, A.; Maiti, D., Nickel-catalyzed hydrogenolysis of unactivated carbon-cyano bonds. Chem. Commun. 2013, 49 (75), 8362-8364 